\title{
Evaluation of Garlic Germplasm for Yield Attributes and Quality Characters from Niche Area of District Jalandhar, India
}

\author{
Balvir Kaur*, Kuldeep Singh and Neena Chawala
}

Krishi Vighan Kendra, Jalandhar, Punjab Agricultural University, Ludhiana, India

*Corresponding author

\begin{abstract}
A B S T R A C T
Genetic variation among populations of cultivated garlic is precious for an economic use of genes and genomes. The collection of cultivated garlic germplasms and its genetic evaluation will identify accessions that could be useful to obtain cultivars using clonal

\section{Keywords}

Garlic, Genotype,

Yield and

biochemical

Article Info

Accepted:

07 March 2020

Available Online:

10 April 2020 selection to be used in breeding programmes. The present investigation was done at Krishi Vigyan Kendra, Nurmahal, Jalandhar during rabi 2017 and 2018 season to critically evaluate seven local varieties collected from the niche area(comparing of 7 villagers from 3 blocks) of district Janlandhar and two recommended varieties of PAU,Ludhiana for selection of better germplasm than check varieties for future breeding programme in garlic. Genotypes were evaluated for yield contributing characters (Plant height , Number of leaves per plant, Bulb weight, Number of cloves per bulb, Weight of individual clove, Bulb yield per hectare (q)) and biochemical composition (Dry Matter ,Total Soluble Solids, Pyruvic acid, Lachrymatory Factor, Reducing Sugars and Alcohol Insoluble Solids). Genotype GL-1 found better for plant height ,weight of individual clove, bulb yield, dry matter pyruvic acid and reducing sugar while it was at par with check varieties in regard to bulb weight, Total soluble solids, lachrymatory Factor and alcohol insoluble solids. Genotypes GL-2 and GL-3 found better and at par with check varieties in regard to most of character under study. These genotype (GL-1, GL-2 and GL3) might be used in further breeding programme for improvment of garlic.
\end{abstract}

\section{Introduction}

Garlic (Allium sativum L.) is one of the important spice crops grown in our country, next to onion. It belongs to the family Alliaceae. It is an herbaceous annual, the underground edible stem of which is a composite bulb made up of a numerous smaller bulbs known as cloves, covered with pinkish or whitish skin. This crop is grown as spice and condiment, though it is treated as a maligned vegetable in India, due to its undesired flavor. It is grown for medicinal usage in pharmaceutical industry also.

The flavor in garlic is easily diagnosed and has anti-infective properties such as power suppliers, insecticidal, antibacterial, antifungal, anti-cancer, lowering of blood sugar, blood lipids and reduction of blood 
platelet aggregation (Agusti, 1990). It is among the most used vegetables for treating Type II diabetes mellitus in diabetic women group from United States (Johnson et al., 2006). Genotypes may also differ in pungency, length of storage, colour, size, number of cloves per bulb, hardiness, and suitability for cooking. Some even store longer, some are more gourmets in flavor and some mature earlier and others later. Garlic shows wide morphological and agronomic variations in colour, size of bulb, plant height, flowering, number and size of the cloves, days to harvesting, resistance to storage capacity, dormancy and adaptation to agroclimatic situations (Mario et al., 2008).

The selection of the cultivar should take into consideration several different factors and characteristics, some of which include the adaptability of the cultivar to the climate of the growing area, the market demand of the particular cultivar and the resistance or tolerance of the cultivar to various pests. Genetic variation among populations of cultivated garlic is precious for an economic use of genes and genomes. The collection of cultivated garlic germplasms and its genetic evaluation will identify accessions that could be useful to obtain cultivars using clonal selection to be used in breeding programmes. In district Jalandhar of Punjab, garlic is grown in particular niche area of garlic which comprising of different villages where all the farmers of marginal land holding are cultivating garlic. The farmers are growing local cultivar and uses their family labour for all the cultivation practices from sowing to harvesting which result in fetching very good price in market. The objectives of this research experiment have to assess genetic variation for plant architecture, yield traits and biochemical analysis of garlic germplasms collected from niche area of district Jalandhar for further use in breeding programme.

\section{Materials and Methods}

The present investigation was done at Krishi Vigyan Kendra, Nurmahal, Jalandhar during rabi 2017 and 2018 season to critically evaluate seven local varieties collected from the niche area of district Janlandhar and two recommended varieties of PAU, Ludhiana for selection of better germplasm than check varieties for future breeding programme in garlic. The niche area comprising of different villages viz. Baupur, Chak Hathiana, Burewal, Parjian, Sangowal, Ismailpur and Biharipur Parjian and in these village more than 80 percent of farming community are cultivating garlic.

Detail of germplam collected is given in the Table 1. The experimental trial was conducted at Krishi Vigyan Kendra, Nurmahal, Jalandhar which is geographically situated at $31^{\circ} 09^{\prime} \mathrm{N}$ latitude, $75^{\circ} 59^{\prime} \mathrm{E}$ longitude and at an altitude of about $237 \mathrm{~m}$ above mean sea level. The experimental site was sandy loam in texture, low in organic carbon (0.31) with available nitrogen (195 kg ha-1), high in available phosphorus (28.7 $\mathrm{kg}$ ha-1) and medium in available potassium (151 kg ha-1) in $0-15 \mathrm{~cm}$ soil depth. Experiment was laid out in randomized complete block design and was replicated thrice. The gross plot size was $25 \mathrm{~m}^{2}$. The sowing of garlic healthy cloves was done during first week of October in both the years. The seed rate used was 5.6 quintal of cloves per hectare.

The cloves were sown with kera method at spacing of $15 \mathrm{~cm}$ between rows and $7.5 \mathrm{~cm}$ between plants in the rows. Twenty tones of well decomposed farmyard manure per hectare was applied 10 days before sowing. In addition $50 \mathrm{Kg}$ Nitrogen and $25 \mathrm{Kg}$ phosphorus in the form of urea, diammonium phosphate respectively was applied. Whole Phosphorous was applied before sowing and Nitrogen applied in three equal splits 30, 45 
and 60 days after sowing. The crop was raised with recommended package of practices by Punjab Agricultural University, Ludhiana. A random sample of ten plants of each genotypes was collected from each plot to estimate the plant height $(\mathrm{cm})$ and number of leaves per plant at 75 days after planting. The uprooting of the cloves was done manually in the first week of May during rabi 2017 and last week April during rabi 2018.

After harvesting, the bulbs were cured and then leaves were cut $1-2 \mathrm{~cm}$ above the neck and bulb yield was recorded. The following observations were recorded during the course of experimentation on yield contributing characters viz. Plant height $(\mathrm{cm})$, Number of leaves per plant, Bulb weight (gm), Number of cloves per bulb, Weight of individual clove $(\mathrm{g})$, Bulb yield per hectare $(\mathrm{q})$.

Under the biochemical composition, data on Dry Matter (\%), Total Soluble Solids (\%), Pyruvic acid (mg/100g), Lachrymatory Factor (mg/100g), Reducing Sugars (\% DW) and Alcohol Insoluble Solids (\% DW) was estimated. The pooled data collected from two season on various parameters under study were statistically analyzed and comparisons were made at 5 per cent level of significance.

\section{Results and Discussion}

Significant variations were observed for different characters. The mean performance of different genotypes for growth and yield attributing characters are presented in Table 2. There is significant difference among all the genotypes for plant Height $(\mathrm{cm})$. It varied from 65.34 to 88.35. Maximum plant height recorded in GL-1(88.35) followed by PG17(81.35), GL-2(77.78), GL-4(75.52) and PG-18(73.60). The genotypes GL-6 recoded minimum plant height (65.34) followed by GL-3(66.53), GL-5(68.95) and GL-7 (70.90). Numbers of leaves were counted after 75 days of planting which varied from 7.00-8.43. Data revealed that number of leaves did not differ significantly among all the genotypes under experimental trial. Weight of 10 randomly selected bulbs from each plot was calculated and their mean was recorded in grams. Data showed significant difference among all type under study and it varied from 20.96 to 28.40.

Maximum bulb weight(gm) was recorded in PG-18 (28.40 g) followed by GL-1(27.43), GL-5(26.19) which was at par with GL-6 (26.56) and GL-3 (26.23) and minimum bulb weight was recorded in GL-7(20.96g) followed by GL-4 (21.60) and GL-2 (24.80) which was at par with PG-17(24.00).Weight of 20 cloves from randomly selected 10 bulbs was recorded and their average was calculated for calculation of weight of individual clove. Data revealed that there was significant difference among all the genotypes under study. Weight of individual clove (no.) varied from 0.9 to 2.3 with average mean value of 1.74 .

Highest weight of individual clove was recorded in GL-1(2.3) which was statistically at par with PG-18(2.2) and GL-5(2.1). The genotype GL-6 recorded minimum weight of individual clove followed by GL-7, GL-4, GL-5, PG-17 and GL-3 and their recorded values were $0.90,1.47,1.50,1.60,1.70$ and 1.90 respectively. Bulb yield is main concern for farmers for better profit market.

Bulb yield ( $q /$ ha) was showed significant difference in all the genotypes under study with mean value of 110.41 (q/ha). The maximum yield was recorded in GL-1(135.43 q/ha) followed by PG-18(127.00 q/ha), PG17(125.00), GL-3(121.40) and GL-2(105.77) while minimum yield was recorded in GL4(91.73), GL-6(94.53) and GL-7(96.62) which was statistically at par with GL-4 (96.23). Maximum fresh weight of bulb, number of cloves per bulb, length, width and 
weight of individual cloves, and bulb yield per hectare was recorded with genotypes Yamuna Safed-3 (G-282) and the minimum remained with local variety Madrasi by Mishra T D and Balaji Vikram (2017). Variations in bulb weight of garlic for different lines are in accordance with the finding of Agarwal and Tiwari (2013).

In the study attributes about the Stem Diameter (mm), number of cloves bulb-1, single clove weight (g) and yield (ton ha-1) the data showed a significant difference. On the basis of the results obtained the mean maximum Bulb diameter $(56.0 \mathrm{~mm})$ and mean maximum yield (8.6ton ha-1) was recorded by the variety Buner Local out of four local varieties evaluated by Muhammad Ibrahim et al., (2018).

Genotypes were tested for biochemical composition like Dry Matter (\%), Total Soluble Solids (\%), Pyruvic acid (mg/100g), Lachrymatory Factor (mg/100g), Reducing Sugars (\% DW) and Alcohol Insoluble Solids (\% DW) which showed significant difference among all the genotypes under study (Table 3). Dry matter (\%) showed significant difference among all the genotypes which ranged from $36.70(\%)$ to $53.98(\%)$.

Highest Dry matter (\%) was evaluated in GL1(53.98) followed GL--2(42.10) and GL$6(40.78 \%)$ which was at par with GL7(40.06\%). Lowest Dry matter (\%) was recorded in GL-4(34.98) followed by PG17(36.70), GL-18(37.86) which was statistically at par with PG-5(37.20).Data revealed significant difference among all the tested genotypes for T.S.S (\%) which ranged from 37.0 to 43.93 with average mean of 39.58.Genotype PG-18 (43.93) exhibits highest T.S.S which was statistically at par with GL-1(43.30) and GL-2(43.1). Genotypes GL-4, GL-7, GL-5 and GL-6 were statistically at par with lowest T.S.S of 37.0,
37.0, 37.3 and 37.7 respectively. The higher TSS value in these genotypes may be due to its inherent characteristics. Similar results of variation were observed by Singh and Chand (2004). Pyruvic acid content as an index to evaluate pungency dependent on the catabolism of S-alk(en)yl-L-cysteine sulphoxide substrate by the enzyme allinase to produce pyruvate, ammonia and a range of both volatile and non-volatile sulphur compounds and estimated by method given by Mehrotra and Hasan (1986).

An increase of pyruvic acid content shows more chief flavor component and pungency. The large amount of pyruvic acid as an indicator of and flavor. Genotypes were differed significantly for pyruvic acid content under study. Genotype GL-1 estimated highest pyruvic acid (33.58) followed by GL3(32.67) and PG -18 (32.66) which were statistically at par with each other. Minimum estimated value for pyruvic acid was estimated in genotype GL-4 followed by GL5(27.07), GL-6 (26.37) and GL-7 (26.95). Sheverin $\left(84.00 \mu \mathrm{mol} \mathrm{g}^{-1}\right)$ and Toein $(84.48$ $\mu \mathrm{mol} \mathrm{g}{ }^{-1}$ ) had the highest pyruvic acid content then followed by Ali Abad $\left(76.80 \mu \mathrm{mol} \mathrm{g}^{-1}\right)$, Barfjin $\left(75.00 \mu \mathrm{mol} \mathrm{g}^{-1}\right)$ and Moein $(73.20$

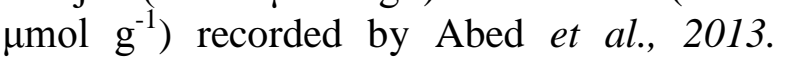
Lachrymatory Factor was measured by method given by Brodnitz and Pascale 1971 in $\mathrm{mg} / 100 \mathrm{~g}$.

It is the chemical responsible for inducing tearing in onion, an undesirable irritant, and it's analogues of which in garlic are known for their health attributes. Genotypes differ significantly for Lachrymatory Factor with average mean value of 22.96. Genotype PG17(25.12) had highest Lachrymatory Factor followed by GL-1(24.88) which was statistically at par with GL-7(24.78) and GL2(24.27). The lowest Lachrymatory Factor was recorded in GL-6(20.45) which was statistically at par with GL-4920.47). 
Reducing Sugars (\% DW) was measured by Somogyi 1952, which estimates monosaccharides and disaccharides having free carbonyl group for the reaction with the other compound. The reducing sugars are generally freely available in plants to provide energy for the growth and act as good nutritional component.

Genotypes did not differ significantly for this character. Alcohol insoluble solids are the remains of the tissue used to extract the sugars and used to calculate the blanched part of dry matter, having useful soluble substances which were estimated by method given by Moyer and Holgate 1948. Data revealed significant difference among all the tested genotypes under experiment. Genotype PG-18 had highest Alcohol insoluble solids followed by PG-17, GL-1 with value of $55.34,50.20$ and 47.17 respectively.

Genotype GL-4(39.76) and Genotype GL2(39.51) were statically at par with each other having lowest estimated value of Alcohol Insoluble Solids. Considering yield potentiality, pungency and other desirable attributes the eight genotype out of twenty two genotypes of local and exotic origin found promising for development of new variety by Islam et al., (2004).

Umar et al., (2015) found similar type of genetic variation for plant architecture and yield traits of 21 genotypes of garlic for plant growth, yield and yield contributing parameter under field condition for two consecutive years and reported genotype RAUG-4 and RAUG-5 promising for further selection.

It can be reasonably be concluded that the results of this study showed that germplasm collected from niche area showed significant variation in agronomical as well as biochemical traits except. Genotype GL-1 found better for plant height, weight of individual clove, bulb yield, dry matter pyruvic acid and reducing sugar while it was at par with check varieties in regard to bulb weight, Total soluble solids, lachrymatory Factor and alcohol insoluble solids.

Table.1 Description of genotype under study

\begin{tabular}{|r|c|c|c|}
\hline Sr.No. & Name of genotype & Block & Village \\
\hline $\mathbf{1 .}$ & GL-1 & Mehatpur & Lohgarh \\
\hline $\mathbf{2 .}$ & GL-2 & Shahkot & Baupur \\
\hline $\mathbf{3 .}$ & GL-3 & Mehatpur & Sangowal \\
\hline $\mathbf{4 .}$ & GL-4 & Mehatpur & Ismailpur \\
\hline $\mathbf{5 .}$ & GL-5 & Shahkot & Chak Hathiana \\
\hline $\mathbf{6 .}$ & GL-6 & Shahkot & Burewal \\
\hline $\mathbf{7 .}$ & GL-7 & Sidhaw Bet & Biharipur Parjian \\
\hline $\mathbf{8 .}$ & PG-17 & Ludhiana & PAU,Ludhian \\
\hline $\mathbf{9 .}$ & PG-24 & Ludhiana & PAU,Ludhian \\
\hline
\end{tabular}


Table.2 Data on yield contributed characters in garlic

\begin{tabular}{|l|c|c|c|c|c|c|}
\hline $\begin{array}{l}\text { Name of } \\
\text { cultivar/c } \\
\text { haracter }\end{array}$ & $\begin{array}{c}\text { Plant } \\
\text { Height } \mathbf{( c m )}\end{array}$ & $\begin{array}{c}\text { No. of } \\
\text { leaves }\end{array}$ & $\begin{array}{c}\text { Bulb } \\
\text { Weight } \\
\text { (gm) }\end{array}$ & $\begin{array}{c}\text { Number of } \\
\text { clove per } \\
\text { bulb (No.) }\end{array}$ & $\begin{array}{c}\text { Weight of } \\
\text { individual } \\
\text { clove(g) }\end{array}$ & $\begin{array}{c}\text { Bulb Yield } \\
\text { /ha }\end{array}$ \\
\hline GL-1 & 88.35 & 8.43 & 27.43 & 14.00 & 2.30 & 135.43 \\
\hline GL-2 & 77.78 & 8.06 & 24.80 & 25.00 & 2.10 & 105.77 \\
\hline GL-3 & 66.53 & 8.03 & 26.23 & 17.67 & 1.90 & 121.40 \\
\hline GL-4 & 75.52 & 8.10 & 21.60 & 25.67 & 1.50 & 91.73 \\
\hline GL-5 & 68.95 & 8.26 & 26.90 & 29.33 & 1.60 & 96.23 \\
\hline GL-6 & 65.34 & 7.00 & 26.56 & 28.00 & 0.90 & 94.53 \\
\hline GL-7 & 70.90 & 7.70 & 20.96 & 28.67 & 1.47 & 96.62 \\
\hline PG-17 & 81.70 & 7.90 & 24.00 & 30.70 & 1.70 & 125.00 \\
\hline PG-18 & 73.60 & 8.23 & 28.40 & 26.20 & 2.20 & 127.00 \\
\hline Mean & 74.29 & 7.97 & 25.21 & 25.03 & 1.74 & 110.4 \\
\hline CD(\%) & 2.5 & 0.53 & 3.1 & 3.2 & 0.39 & 5.0 \\
\hline
\end{tabular}

Table.3 Biochemical Composition of Garlic genotypes

\begin{tabular}{|l|c|c|c|c|c|c|}
\hline $\begin{array}{l}\text { Name } \\
\text { of cultivar/ } \\
\text { character }\end{array}$ & $\begin{array}{c}\text { Dry } \\
\text { Matter } \\
(\boldsymbol{\%})\end{array}$ & $\begin{array}{c}\text { Total } \\
\text { Soluble } \\
\text { Solids } \mathbf{( \% )}\end{array}$ & $\begin{array}{c}\text { Lachrymat } \\
\text { ory Factor } \\
(\mathbf{m g} / \mathbf{1 0 0 g})\end{array}$ & $\begin{array}{c}\text { Pyruvic } \\
\text { acid } \\
(\mathbf{m g} / \mathbf{1 0 0 g})\end{array}$ & $\begin{array}{c}\text { Reducing } \\
\text { Sugars } \mathbf{\%} \\
\text { DW) }\end{array}$ & $\begin{array}{c}\text { AIS } \\
(\mathbf{\%} \text { DW) }\end{array}$ \\
\hline GL-1 & 53.98 & 43.30 & 33.58 & 24.88 & 3.36 & 47.17 \\
\hline GL-2 & 42.10 & 43.1 & 30.73 & 22.47 & 4.10 & 39.51 \\
\hline GL-3 & 39.44 & 38.3 & 32.67 & 24.27 & 4.76 & 38.34 \\
\hline GL-4 & 34.98 & 37.0 & 25.65 & 20.47 & 4.88 & 39.76 \\
\hline GL-5 & 37.20 & 37.3 & 26.07 & 21.98 & 4.76 & 40.00 \\
\hline GL-6 & 40.78 & 37.7 & 26.37 & 20.45 & 4.57 & 42.81 \\
\hline GL-7 & 40.06 & 37.0 & 26.95 & 24.78 & 3.35 & 40.00 \\
\hline PG-17 & 36.70 & 38.57 & 30.60 & 25.12 & 4.0 & 50.20 \\
\hline PG-18 & 37.86 & 43.93 & 32.66 & 22.12 & 2.3 & 55.34 \\
\hline Mean & 40.50 & 39.58 & 29.47 & 22.96 & 4.01 & 43.68 \\
\hline CD $(\boldsymbol{\%})$ & 2.7 & 2.24 & 2.8 & 2.5 & 0.56 & 1.7 \\
\hline
\end{tabular}

Genotypes GL-2 and GL-3 found better and at par with check varieties in regard to most of character under study. These genotype (GL-1, GL-2 and GL-3) might be used in further breeding programme for improvement of garlic.

\section{References}

Abedi, M., Biat, F., and Nosrati A.E. 2013. Evaluation of Agronomical Traits and Pyruvic Acid Content in Hamedan Garlic (Allium sativum L.) Ecotypes. World Applied Sciences Journal. 22(5): 628-631. 
Agarwal, A. and. Tiwari, R. S. 2013. Evaluation of garlic (Allium sativum) genotypes for yield and susceptibility to purple blotch. Acad. J., 5: 48-52.

Agusti, K. T. 1990. Therapeutic and medicinal values of onions and garlic. In: Onions and Allied Crops. (Brewster, J. L and Rabinowitvh, H. D. Eds) $C R C$ Press, Inc., Pp 99-104.

Brodnitz M. H and Pascale J. V. 1971. Thiopropanal S-oxide: a lachrymatory factor in onions. $J$ Agric Food Chem., 19(2):269-272.

Islam, M.J., Islam M.A.,Akter Tania S, Saha S.R, Alam M.S. and Hasan M.K. 2004. Performance Eva luation of Some Garlic Genotypes in Bangladesh. Asian Journal of Plant Science, 3(1):14-16.

Johnson, L., Strich, H., Taylor, A., Timmermann, B., Malone, D., TenfelShone, N., Drummond, R., Woosley, R., Pereira, E. and Martinez, A. 2006. Use of herbal remedies by diabetic Hispanic women in the Southwestern United States. Phytotherapy Research., 20: 250-255.

Kumar, U and Prasad, B.2015 Evaluation of garlic (Allium sativum L.) genotypes for plant architecture and yield. Journal Crop and Weed., 11(1):128-131.

Mario, P. C., Viviana, B.V and Marya I. A. 2008.Low genetic diversity among garlic accessions detected using RAPD. Chilean Journal of Agricultural Research., 68:3-12.

Mehrotra R. N and Hasan T. 1986. Detection and Spectrophotometric Determination of Pyruvic Acid. Analytical letters., 19: 1713-24.

Mishra T.D and Balaji Vikram. 2017. Evaluation of Garlic (Allium sativum L.) germplasms for yield potential and quality characters under Allahabad agro-climatic conditions. Journal of Pharmacognosy and Phytochemistry., 2017; 6(6): 433-436

Moyer J. C and Holgate K. C. 1948. Determination of alcohol-insoluble solids and sugar contents of vegetables. Anal Chem., 20 (5): 472-44.

Muhammad Ibrahim1, Shafiullah1, Muhammad Ilyas1, Faraz Ali Shah, Abid Khan, Shah Rukh and Inzimam Ul Haq.2018. Comparison of Different Garlic (Allium sativum) Varieties for Yield and Yield Components Grown at Agriculture Research Station, Buner. Int J Environ Sci Nat Res., 13(5):1-5.

Singh, Chand R. 2004. Genetic variability in garlic. Haryana J. Horti. Sci., 33(1/2):146-147.

Somogyi M. 1952. Note on sugar determination. J Biol Chem., 195(1):1923.

\section{How to cite this article:}

Balvir Kaur, Kuldeep Singh and Neena Chawala. 2020. Evaluation of Garlic Germplasm for Yield Attributes and Quality Characters from Niche Area of District Jalandhar, India. Int.J.Curr.Microbiol.App.Sci. 9(04): 706-712. doi: https://doi.org/10.20546/ijcmas.2020.904.084 